\title{
Academic Writing: Theory and Practice
}

\author{
Brian V. Street (Corresponding author) \\ School of Education \\ King's College London, University of London, London, UK \\ E-mail: bvstreet@gmail.com
}

Received: September 12, 2015 Accepted: November 18, 2015

Published: November 26, 2015

doi:10.5296/jei.v1i2.8314 URL: http://dx.doi.org/10.5296/jei.v1i2.8314

\begin{abstract}
In this paper I attempt to locate the study of academic writing in the broader field of Literacies as Social Practice. I begin with a brief summary of recent theories of Literacies as Social Practice and then recount some of the ethnographic methods for studying these. I then discuss the application of these concepts to academic writing in Higher education, including university, not just school and support for teachers as well as students. This involves notions of 'academic language and literacies' and I cite a paper on this entitled 'modelling for diversity' based on a research project in London, including issues of how English language is addressed, and the complexity involved in the diversity currently evident (Leung \& Street, 2014). I conclude by drawing out some of the implications of this work for both theory and practice.
\end{abstract}

Keywords: Academic writing, Literacies as Social Practice (LSP), Higher education

\section{Social Literacies Research}

Much of the work in the tradition, which I now refer to as 'Literacies as Social Practice' (LSP), focuses on the everyday meanings and uses of literacy in specific cultural contexts and links directly to how we understand the work of literacy programmes, which themselves then become subject to ethnographic enquiry.

In trying to characterise these new approaches to understanding and defining literacy, I have referred to a distinction between an 'autonomous' model and an 'ideological' model of literacy (Street, 1984). The 'autonomous' model of literacy works from the assumption that literacy in itself - autonomously - will have effects on other social and cognitive practices, as in the early 'cognitive consequences' literature. The model, I argue, disguises the cultural and ideological assumptions that underpin it and that can then be presented as though they are 
neutral and universal. Research in the social practice approach challenges this view and suggests that in practice dominant approaches based on the autonomous model are simply imposing western (or urban etc.) conceptions of literacy on to other cultures (Street, 2001). The alternative, ideological model of literacy offers a more culturally sensitive view of literacy practices as they vary from one context to another. This model starts from different premises than the autonomous model - it posits instead that literacy is a social practice, not simply a technical and neutral skill; that it is always embedded in socially constructed epistemological principles. The ways in which people address reading and writing are themselves rooted in conceptions of knowledge, identity and being. Literacy, in this sense, is always contested, both its meanings and its practices, hence particular versions of it are always 'ideological', they are always rooted in a particular world-view and a desire for that view of literacy to dominate and to marginalise others (Gee, 1990). The argument about social literacies (Street, 1995) suggests that engaging with literacy is always a social act even from the outset.

\subsection{Literacy Events and Literacy Practices}

Key concepts in the field that may enable us to apply these new approaches to literacy to specific contexts and practical programmes include the concepts of literacy events and of literacy practices. Shirley Brice Heath characterised a 'literacy event' as 'any occasion in which a piece of writing is integral to the nature of the participants' interactions and their interpretative processes' (Heath, 1982, p. 50). I have employed the phrase 'literacy practices' (Street, 1984, p. 1) as a means of focussing upon 'the social practices and conceptions of reading and writing', although I later elaborated the term both to take account of 'events' in Heath's sense and to give greater emphasis to the social models of literacy that participants themselves bring to bear upon those events and that give meaning to them (Street, 1988).

In a paper on this (Street, 2000, p. 22) I distinguished 'literacy events' from 'literacy practices' in the following way:

'The concept of literacy practices ... attempts to handle the events and the patterns of activity around literacy but to link them to something broader of a cultural and social kind. And part of that broadening involves attending to the fact that in a literacy event we have brought to it concepts, social models regarding what the nature of this practice is and that make it work and give it meaning. Those models we cannot get at simply by sitting on the wall with a video and watching what is happening: you can photograph literacy events but you cannot photograph literacy practices.'

\section{Ethnographic Perspectives}

A key claim in the LSP field is that 'Literacy practices can only be understood in relation to the social, cultural, historical and political contexts in which they take place.' So, the question then arises, 'how do we find out about such practices and contexts?' One response is to proffer an ethnographic perspective that enables us to listen, hear and see what people are doing with literacy and to engage with their local meanings.

In order to arrive at an empirical description of what takes place when people communicate 
with one another in any specific situation, Hymes (1996) suggests that we should try to find out about the language and other semiotic resources being used, how these resources are being used and evaluated by participants, and more importantly from the point of view of descriptive adequacy we should ask questions such as 'whether (to what degree) something is in fact done, actually performed, and what it's doing entails'. Hymes - and others in the Ethnography of Communication tradition - recognise the importance of an "emic" rather than an "etic" perspective, focussing on the meanings of participants rather than simply imposing our own from outside.

\subsection{Doing Ethnography/Adopting an 'Ethnographic Perspective'}

In introducing ethnographic perspectives to education students, on research training courses, I have found that they sometimes feel bullied by anthropologists' claims to the concept of ethnography. A useful antidote to this has been a paper by Green and Bloome (1997) which makes a helpful distinction between 'doing ethnography'-used to describe on the one hand both what anthropologists do using fieldwork methods over a lengthy period and the product ie writing 'an ethnography' - and on the other, adopting an 'ethnographic perspective', which takes 'a focused approach to studying particular aspects of everyday life and cultural practices of a social group'. Central to an ethnographic perspective is 'the use of theories of culture and inquiry practices derived from a variety of disciplines eg. Cultural Studies, SocioLinguistics, Education, to guide the research'. Some of the work in Literacy as Social Practice (LSP), including teacher inquiry and participatory project research, may be aptly termed 'ethnographic perspective', a principle that we might apply in this context.

\section{Application of Theories and Methodology Regarding Literacies as Social Practice to Academic Writing}

In 1995 Mary Lea and I were awarded an ESRC grant on academic literacies and we proceeded to carry out research in a number of universities in the UK. In retrospect, we described the research as involving a period when

$>\quad$ 'we looked at perceptions and practices of student writing in higher education taking as case studies one new and an old university in Southern England. Set against the background of numerous changes in higher education in the UK and increasing numbers of non-traditional entrants, this research has been concerned with a wider institutional approach to student writing, rather than merely locating the problem with individual students. One of the main purposes of the research has been to move away from a skills based, deficit model of student writing and to consider the complexity of writing practices that are taking place at degree level in universities. Staff and students were interviewed in both institutions about their perceptions and interpretations of what is required in completing written assignments and about the problems that are identified in student writing. As a starting point, the research adopts the concept of academic literacies as a framework for understanding university writing practices (Lea \& Street, 1998).

Following from this research, Mary Lea and I published an article in Studies in Higher Education (Lea \& Street, 1998), which attracted a great deal of attention in the fields of 
literacy studies and higher education studies and, latterly, English for Academic Purposes. Our 1998 article is interestingly, still cited as one of the most referenced in the journal Studies in Higher Education.

We put forward three 'models' that participant university staff were seen to hold regarding student writing. In particular, the 'study skills' model dominated much theory and practice at the time but, as this article demonstrated and subsequent studies have reinforced and developed, the reality on the ground is of multiple requirements on student writing according to context, varying with discipline but also, inter alia, with institutional pressures including issues of funding, and the role of subject tutors not just students. Whilst the development of what we termed the 'academic socialisation' model, did attempt to take account of some of these issues, by 'socialising' students into the demands of the academy, we argued that the 'Academic Literacies' (Aclits) approach, could help extend further our understanding and practice in this field. Aclits requires researchers to investigate and practitioners to take account of the variety of academic literacy practices evident in particular contexts; this includes negotiating new and varied genres of writing; different disciplinary requirements in terms of argumentation, information structuring and rhetorical styles; and different teacher preferences.

Such variation and complexity meant that two of the models - study skills and academic socialisation - whilst often providing a useful starting point, were too narrowly drawn to take account of the actual range of needs and demands and practices around writing in the university.

\section{Application of this Work to Academic Writing in Higher Education}

In the Literacy field, then, it has been recognized that it is not appropriate, especially in international contexts, to conceptualize a single, uniform notion of 'literacy' —rather there are 'multiple literacies'. The dominant model in many countries has tended to be that studentsespecially 'non traditional' students - are somehow 'in deficit', they 'can't write' as many Tutors say. A solution to this has been to create centralised 'Study Skills' Programmes that address some of the formal, linguistic features that students struggle with, but these often fail to address the subject specific genres and discourses involved.

The 'Academic Literacies' approach attempts to address this issue by presenting a more complex, 'social practice', perspective. In the light of these approaches, the Academic Literacies perspective makes some of the following suggestions:

$>$ Both Tutors and Students need to take account of more complex explanations and responses to issues associated with student writing than the simple 'deficit' model一'students can't write'...

$>$ Theoretical approaches to academic writing need to take into account the 'social practices' approach rather than focussing primarily on a 'skills' approach: this involves concepts such as Genre, 'Didactics', 'Discourse' that recognise how what counts as writing may vary across contexts, especially courses, institutions and countries. 


\section{Language Issues}

Applying some of these social practice approaches to the study of language has also led to a more complex, 'diverse' view of language acquisition and study-including what counts as 'English'. Martin-Jones (2012, p. 1) explains:

'Over the last two decades, sociolinguistic research on multilingualism has been transformed. Two broad processes of change have been at work:

Firstly, there has been a broad epistemological shift to a critical and ethnographic approach, one that has reflected and contributed to the wider turn, across the social sciences, towards critical and poststructuralist perspectives on social life. Secondly, over the last ten years or so, there has been an intense focus on the social, cultural and linguistic changes ushered in by globalisation, by transnational population flows, by the advent of new communication technologies, by the changes taking place in the political and economic landscape of different regions of the world. These changes have had major implications for the ways in which we conceptualise the relationship between language and society and the multilingual realities of the contemporary era. A new sociolinguistics of multilingualism is now being forged: one that takes account of the new communicative order and the particular cultural conditions of our times, while retaining a central concern with the processes involved in the construction of social difference and social inequality' (see also Blommaert, 2013).

\subsection{Leung and Street Research on 'Academic Language and Literacies: Modelling for Diversity'}

In the spirit of such 'diverse' understanding of language and literacy, Constant Leung and I conducted research in London schools taking account of social practices perspectives. Our main objectives were to research the following questions:

1. What academic language and literacy practices, with respect to oral interaction, reading and writing, do the students and teachers engage in, within specified disciplines under investigation?

2. What are the expected uses of academic literacy with respect to reading and writing in curriculum assignments e.g. essays, reports etc.?

3. How do students from diverse ethnic, social and linguistic backgrounds engage with and respond to the requirements for academic language and literacy practices evident in their specific disciplines and contexts?

The project aimed to address these questions by building on work in the fields of academic literacies and English as an additional/second language (EAL/ESL). In many of the classes we observed there was a complex mix of sources of information: in different modes - written, spoken, visual; and in different locations. We observed (Leung \& Street, 2014) that language is but one facet of communication: "It is clearly the case that it is no longer sufficient to be able to use English (indeed any named language) in the conventional sense of being able to understand and express meaning through words and sentences, when much of what we do in digitally mediated communication involves the use of a mixture of language, visual-audio 
and other semiotic resources, and technical know-how to navigate and exploit the technological facilities on computers and mobile devices.'

Given these complexities, there is a good case for asking the question 'How is literacy construed and enacted by teachers and students across the curriculum?' As part of this orientation, we are interested in the ways in which language, in this case English, is used for communicative purposes (including reading and writing) in school contexts.

\section{Conclusions}

$>$ Shift to social approaches to literacy, language and education;

$>$ Ethnographic approach involves trying to find out what these mean to the participants;

$>$ Education can adjust to these principles and findings e.g. tutors not just students need support;

$>$ Move beyond narrow view of 'Language', e.g. 'English' and instead work with diversity.

\section{References}

Blommaert, J. (2013). Writing as a sociolinguistic object. Journal of Sociolinguistics, 17(4), 440-459. http://dx.doi.org/10.1111/josl.12042

Crème, P., \& Lea, M. (1997). Writing at University: A guide for students. Open University Press: Buckingham.

Gee, J. P. (1990). Orality and Literacy: From the Savage Mind to Ways with Words. Social Linguistics and Literacy: Ideology in Discourses. London: Falmer Press.

Green, J., \& Bloome, D. (1997). Ethnography and ethnographers of and in education: A situated perspective. In J. Flood, S. Heath, \& D. Lapp (Eds.), A handbook of research on teaching literacy through the communicative and visual arts (pp. 181-202). New York, Simon and Shuster Macmillan.

Heath, S. B. (1983). Ways with Words. Cambridge: CUP.

Heath, S. B. (1993). The madness(es) of reading and writing ethnography. Anthropology \& Education Quarterly, 24(3), 256-68. http://dx.doi.org/10.1525/aeq.1993.24.3.05x0971i

Hymes, D. (1996). Ethnography, Linguistics, Narrative Inequality: Towards an understanding of voice. Taylor \& Francis: London.

Lea, M. R., \& Street, B. V. (2006). The 'Academic Literacies' Model: Theory and Applications. Theory into Practice Fall, 45(4), 368-377. http://dx.doi.org/10.1207/s15430421tip4504_11

Lea, M., \& Street, B. (1998). Student Writing and Faculty Feedback in Higher Education: An Academic Literacies Approach. Studies in Higher Education, 23(2). http://dx.doi.org/10.1080/03075079812331380364

Leung, C. (2015). Additional/Second language academic literacies: Grounding pedagogy in 
language practices. Encyclopedia of Language and Education. Springer.

Leung, C., \& Street, B. (2014). Researching Academic Language and Literacies in Ethnolinguistically Diverse Classrooms. In M. Prinsloo \& C. Stroud (Eds.), Educating for Language and Literacy Diversity. Palgrave Macmillan.

Martin-Jones, M., \& Jones, K. (2000). 'Introduction' to Multilingual Literacies: Comparative Perspectives on Research and Practice. Amsterdam: John Benjamin's.

Street, B. (1984). Literacy in Theory and Practice. CUP: Cambridge

Street, B. (1995). Social Literacies: Critical approaches to literacy in Development. London: Ethnography and Education Longman.

Street, B. (2000). 'Literacy Events and Literacy Practices' in Multilingual Literacies: Comparative Perspectives on Research and Practice (pp. 17-29). In M. Martin-Jones \& K. Jones (Eds.). Amsterdam: John Benjamin's.

\section{Copyright Disclaimer}

Copyright for this article is retained by the author(s), with first publication rights granted to the journal.

This is an open-access article distributed under the terms and conditions of the Creative Commons Attribution license (http://creativecommons.org/licenses/by/3.0/). 